\title{
Screening For Vitamin D Deficiency In Females In Madina Region; Saudi Arabia. Vitamin D Deficiency In A Sunny Environment
}

\author{
Eman Nagib(1) and Mahmoud A. Abulmagd ${ }^{(2)}$ \\ 1-Internal Medicine department-Ain Shams,2-Endocrinology department-Banha
}

\begin{abstract}
Background And Objective: Poor sunlight exposure leads to vitamin D deficiency even in the sunniest places. So screening for vitamin D deficiency in outpatient clinics and inhospital setting in King Fahad Hospital, Al Madina Al Monwara.

METHODS: Screening for vitamin D deficiency by assessment of serum 25(OH)D with radioimmunoassay in 60 female patients aged $18-40$ years. Serum calcium, phosphorous and alkaline phosphatase were assessed, too.

Results: 6 female patients (10\%) showed significant vitamin D deficiency with $25(\mathrm{OH}) \mathrm{D}<20$ $\mathrm{ng} / \mathrm{ml}$. However 54 female patients $(90 \%)$ showed severe vitamin D deficiency with $25(\mathrm{OH}) \mathrm{D}<10$ $\mathrm{ng} / \mathrm{ml}$.
\end{abstract}

Conclusion: Vitamin D deficiency is very common in Saudia Arabia especially females due to poor sunlight exposure. So being underrecognized and undertreated, vitamin D deficiency represents an important health problem in MADINA REGION, KSA.

( Key words : Vitamin D, Sunlight exposure, Females )

\section{Introduction}

Ultraviolet $\beta$ radiation produces $90 \%$ of vitamin $\mathrm{D}$ in human beings and only very small proportions can be produced through diet [The Lancet (Editorial), 2010]. Poor sunlight exposure leads to vitamin $\mathrm{D}$ deficiency as in elderly housebound and Asian women who cover their bodies with clothes [Turner,2009] Vitamin D insufficiency although widely prevalent is still under-recognized and undertreated [Thacher,2011]. The diagnosis of vitamin D deficiency is often missed as symptoms develop slowly and are nonspecific [Barclay,2009] A cutoff value of $30 \mathrm{ng} / \mathrm{ml}$ is sometimes used for vitamin D status, at which there is a plateau in suppression of PTH [Thacher,2011]. So concentrations of $25(\mathrm{OH})$ D over approximately $30 \mathrm{ng} / \mathrm{ml}$ are generally considered sufficient. Those between 8 and 30 $\mathrm{ng} / \mathrm{ml}$ are insufficient with increased fracture risk and decreased calcium absorption. Concentrations less than $8 \mathrm{ng} / \mathrm{ml}$ may be associated with osteomalacia [Painter,2007]. More recently studies have reported inverse associations between levels of serum $25(\mathrm{OH})$ $\mathrm{D}$ and the risk of wide range of diseases including cancer, vascular disease, infectious conditions, autoimmune diseases, osteoporosis, 
type 2 diabetes mellitus, and obesity[Grey,2010].

\section{Patients And Methods}

This study in $\mathrm{KFH}$, Al Madina Al Monawara included 60 female patients aged 18 to 40 years, and a questionnaire was completed face-to-face. Blood samples were collected for serum $25(\mathrm{OH}) \quad \mathrm{D}$, as the serum 25hydroxyvitamin $\mathrm{D}[25(\mathrm{OH}) \mathrm{D}]$ concentration is a widely accepted indicator of vitamin D status so Serum25(OH) D was assessed by radioimmunoassay. calcium, phosphorous, alkaline phosphatase, fasting blood glucose \& thyroid function test. Those patients were selected from Endocrinology and General Medicine outpatient clinics and inpatient medical wards.

Exclusion criteria were:-patients with chronic kidney diseases ,patients on regular hemodialysis, those with osteoporosis on treatment, hyperparathyroidism ,patients on vitamin D supplements\& pregnant females .

\section{Results}

This study showed that all patients had vitamin D deficiency [VDD] in either severe or significant forms, 6 female patients (10\%) showed significant vitamin D deficiency with $25(\mathrm{OH}) \mathrm{D}<20 \mathrm{ng} / \mathrm{ml}$. However, 54 patients (90\%) showed severe vitamin D deficiency with $25(\mathrm{OH}) \mathrm{D}<10 \mathrm{ng} / \mathrm{ml}$. Seven patients only showed hypocalcemia ranging from 1.26 - $2.05 \mathrm{mmol} / \mathrm{L}$. All other patients showed normal serum calcium. Serum phosphorous was normal in all patients studied. Serum alkaline phosphatase was higher than normal range in 4 patients only.

Table 1:- Associated Hypothyroidism \& Type II DM with Vit D deficiency

\begin{tabular}{|l|l|l|}
\hline Patient group & $\begin{array}{l}\text { Associated } \\
\text { Hypothyroidism }\end{array}$ & Associated type 2 DM \\
\hline Severe vitamin D deficiency & 12 & 10 \\
\hline Vitamin D deficiency $<20 \mathrm{ng} / \mathrm{dl}$ & 6 & No \\
\hline
\end{tabular}

Table 2:- Presence of symptoms of vitamin D deficiency

\begin{tabular}{|l|l|l|}
\hline Patient group & Fatigue & Muscle pain \& bony aches \\
\hline Severe vitamin D deficiency & 3 patients & 2 patients \\
\hline Vitamin D deficiency $<20 \mathrm{ng} / \mathrm{dl}$ & No & No \\
\hline
\end{tabular}

Table 3Relation between (serum Ca, Alkaline Phosphatase, and Phosphorus ) \& ( Vit. D level )

\begin{tabular}{|l|l|l|}
\hline Vit. D level & $\begin{array}{l}\text { Severe Deficiency Gp } \\
(<10 \mathrm{ng} / \mathrm{dl})\end{array}$ & $\begin{array}{l}\text { Significant Deficiency Gp } \\
(<20 \mathrm{ng} / \mathrm{dl})\end{array}$ \\
\hline Ser. $C a$ & Decreased & Normal \\
\hline Ser. $P$ & Normal & Normal \\
\hline Ser. Alk. Phosphatase & Increased & Normal \\
\hline
\end{tabular}


Fig. 1Screening of vit. D deficiency in sunny environment

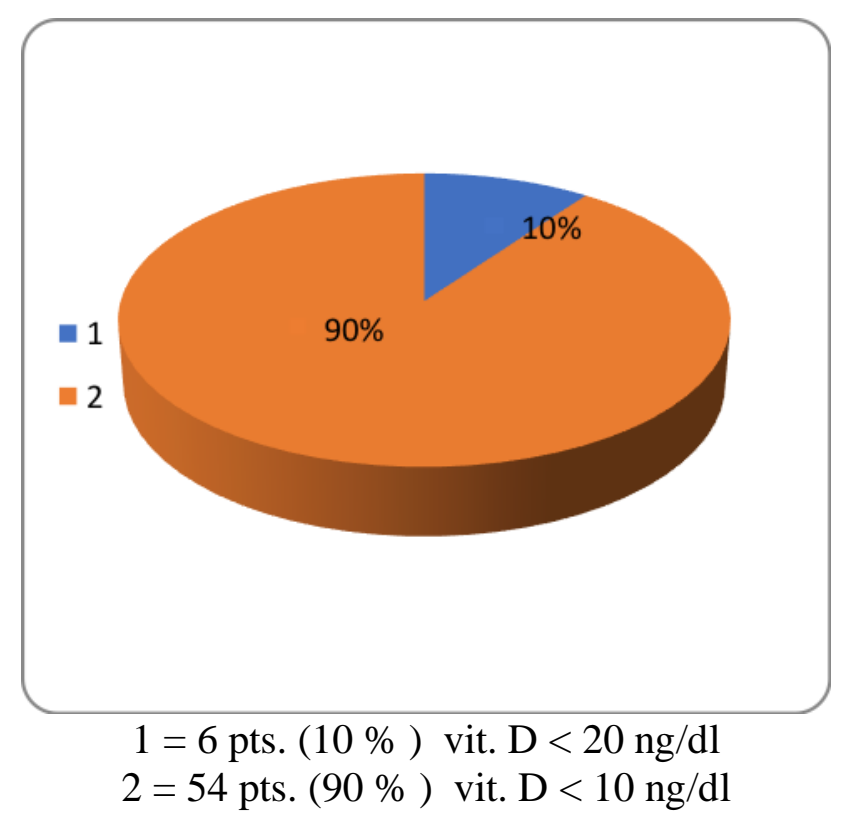

\section{Discussion}

The characteristics of $1,25(\mathrm{OH})_{2} \mathrm{D}$ are those of a hormone and consequently vitamin $\mathrm{D}$ is a prohormone rather than a true vitamin [Thacher,2011].Vitamin D increases gut absorption of calcium and phosphate, increases renal reabsorption of calcium and phosphate, decreases parathyroid production of PTH, and maintains a favorable calcium - phosphate product necessary for normal bone mineralization [Sanders,2005]. Potential non skeletal benefits of vitamin D include low cardiovascular mortality, reduced risk of diabetes mellitus, reduced risk of cancer and reduced risk of infection [Thacher,2011]. Significant vitamin D deficiency is defined as serum $25(\mathrm{OH}) \mathrm{D}<$ $50 \mathrm{nmol} / \mathrm{L} \quad(<20 \mathrm{ng} / \mathrm{ml})$. However if
$25(\mathrm{OH}) \mathrm{D}$ is $<25 \mathrm{nmol} / \mathrm{L}(<10 \mathrm{ng} / \mathrm{ml})$ severe vitamin $\mathrm{D}$ deficiency is diagnosed [Fitzgerald,2008]. As long as sunlight exposure is adequate $1,25(\mathrm{OH})_{2} \mathrm{D}$ can be produced in the body without requirement for ingestion in the diet [Thacher,2011]. In the sunniest places such as Saudi Arabia and Australia $30 \%$ to $50 \%$ of adults and children have deficient or insufficient levels of vitamin D [ Holick, 2007].

Vitamin D deficiency among healthy young Saudi women of 25- 35 years was $30 \%$ [ Al-Turki,2008] . However another study showed that the prevalence of vitamin $\mathrm{D}$ deficiency in adolescent school girls in Jeddah, Saudi Arabia, was 
$81 \%$ with very low levels of vitamin D in approximately 40\% [Siddiqui, 2007].

Our study showed that all female patients studied has vitamin D insufficiency below $30 \mathrm{ng} / \mathrm{ml}$. Of those $10 \%$ have significant vitamin D deficiency $<20 \mathrm{ng} / \mathrm{ml}$, and 90\% have severe vitamin D deficiency $<10 \mathrm{ng} / \mathrm{ml}$. Poor sunlight exposure is the likely cause of vitamin D deficiency in our study. Vitamin D deficiency which classically manifests in adults as osteomalacia is characterized by impaired bone mineralization [ Thacher,2011]. Furthermore vitamin D deficiency is one of the secondary causes of osteoporosis [Painter,2007].

Serum $25(\mathrm{OH}) \mathrm{D}$ is the most stable and plentiful metabolite of vitamin $\mathrm{D}$ in human, which has half life of about 3 weeks [ Thacher,2011], and is the main storage form of vitamin D [Turner,2009] making it the most suitable indicator of vitamin D status [Thacher,2011].

To obtain adequate sunshine vitamin $\mathrm{D}$, the face, arms, hands or back must have sun exposure without sunscreen for $15 \mathrm{~min}$ at least twice weekly. In sunlight deprived individuals (e.g. veiled women or confined patients), the recommended daily allowance of vitamin
D should be 1000 IU daily [AlTurki,2008]. The previously mentioned measures could be the available weapons to fight an expected epidemic of vitamin D deficiency in kingdom of Saudi Arabia. In adults vitamin D supplementation reduces the risk of fractures and falls [Thacher,2011].

\section{References}

1. Al - Turki HA, sadat - Ali M, Al-Elq AH, Al-Mulhim FA. 25 - Hydroxy vitamin D levels among healthy Saudi Arabian Women. Saudi Med J. 2008; Dec, 29(12): 1765- 8.

2. Barclay L. Management of vitamin D deficiency Reviewed. Med Scape Medical news. 2009; November.

3. Fitzgerald PA. Osteomalacia. Current Medical Diagnosis and treatment. 2008; 998 -99

4. Grey A and Bolland M. Vitamin D. A place in the sun. Arch Intern Med. 2010; 170(13) : 1099 - 1100

5. Holick MF. Vitamin D deficiency. N Engl J Med. 2007; 357 (3) : 266-81.

6. Painter SE and Camacho PM. Metabolic bone disease. Evidence based endocrinology. 2007.

7. Sanders LR. Hypercalcemia. Endocrine secrets. 2005, $130-31$.

8. Siddiqui AM and Kamfar HZ. Vitamin D deficiency in adolescent school girls in Jeddah, Saudi Med J. 2007; Mar, 28(3): 441-4.

9. Thacher TD and Clarke BL. Vitamin D deficiency. Mayoclinic Proc. 2011; 86(1) : $50-56$.

10. The Lancet [Editorial], Lighting the way to better health : vitamin D. Lancet (2010), $376: 142$.

11. Turner HE and Wass JA(2009). Vitamin D deficiency. Oxford handbook of endocrinology and diabetes, 466 and 498. 


\section{البحث عن نقص فيتامين د في الإناث في منطقة المدينة المنورة

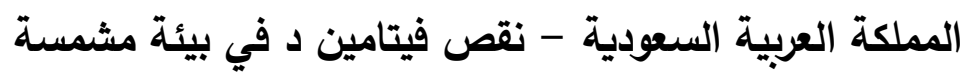

$$
\begin{aligned}
& \text { إيمان نجيب1 ومحمود عبد الوهاب (2) } \\
& \text { (1) قسم الباطنة العامة ـ (2) قسم الغدد الصماء }
\end{aligned}
$$

الخلفية والأهداف : إن قلة التعرض لأشعة الثمس تؤدي إلى نقص فيتامين د حتى في المناطق

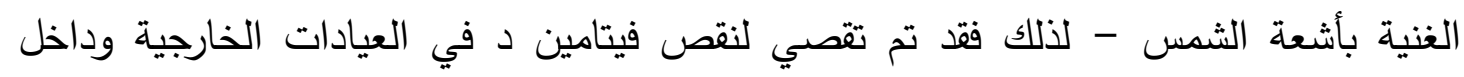
مستثفى الملك فهز بالمدينة المنورة . لمعنة

المواد والطرق : تقصي لنقص فيتامين د بتحديد مستوى 25 (هيدروكسي) فيتامين د في مصل

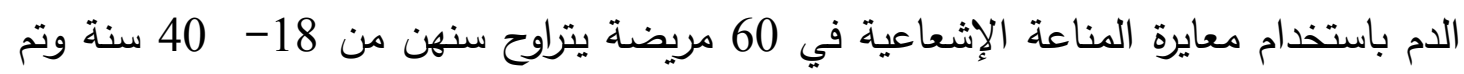

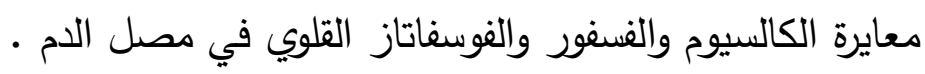

النتائج : أظهرت 6 من المرضى الإناث (10\%) نقص هام لفيتامين د بانخفاض 25

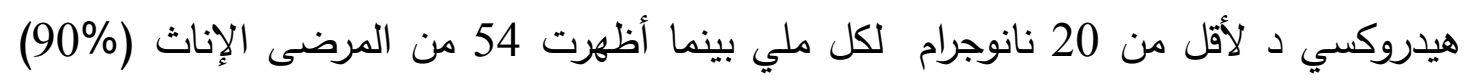

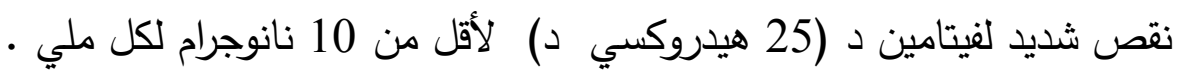

الاستنتاج : إن نقص فيتامين د شائع جدًا في المملكة العربية السعودية خاصة الإناث نتيجة لقلة

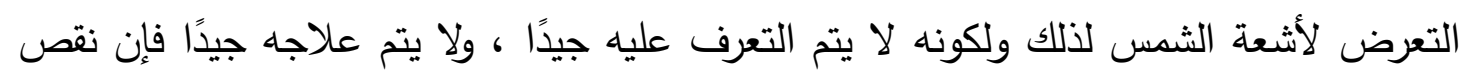
فيتامين د يمثل مشكلة صحية هامة في المملكة العربية السعودية. 